\title{
O PACTO NIETZSCHE - ARISTÓFANES NA CRÍTICA A SÓCRATES EM O NASCIMENTO DA TRAGÉDIA
}

\begin{abstract}
Adriany Ferreira é Professora Adjunta de Filosofia da Educação do Instituto de Filosofia e Ciências Sociais da UFRJ (IFCS-UFRJ), Doutora em Filosofia pela Universidade do Estado do Rio de Janeiro (UERJ) e integrante do grupo de pesquisa SpiN.

E-mail: adrianyfm@globo.com
\end{abstract}

\begin{abstract}
Resumo
O objetivo deste artigo é discutir em que medida, em seu primeiro livro, para além da aproximação com as filosofias de Kant e Schopenhauer que lhe permite fazer a crítica ao racionalismo socrático e o elogio da tragédia ática, Nietzsche estabelece um pacto silencioso e ainda mais profundo com a perspectiva cômica desenvolvida por Aristófanes como forma de estabelecer a imagem pejorativa de Sócrates como o inimigo da arte trágica.
\end{abstract}

\begin{abstract}
The goal of this paper is to discuss to which extent, in Nietzsche's first book, beyond his approximation to the philosophies of Kant and Schopenhauer which allows him to criticize Socratic rationalism and to praise Athenian tragedy, he establishes a silent and even more profound pact with the comic perspective developed by Aristophanes as a way to set a pejorative image of Socrates as the enemy of tragic art.
\end{abstract}

Nos dois últimos anos de sua atividade filosófica, Nietzsche desenvolve uma espécie de olhar retrospectivo sobre sua obra e faz uma série de comentários acerca de seus escritos anteriores. Tais textos foram publicados como novos prefácios para seus livros e também integram sua autobiografia Ecce Homo. O próprio Nietzsche faz questão de evidenciar na Tentativa de Autocrítica, segundo prefácio escrito para $O$ Nascimento da Tragédia - e no capítulo de Ecce Homo, em que comenta seu livro de estreia - sua contraposição à tradição de pensamento ocidental, discussão que ocupa um lugar central no conjunto das teses de $O$ Nascimento da Tragédia.

Esta contraposição tem seu ponto inicial em uma rejeição do próprio ato de fundação do pensamento racional de origem socrático platônica. Partindo de ataques dirigidos mais diretamente à figura de Sócrates, Nietzsche faz uma análise crítica do racionalismo socrático (meio pelo qual o discurso filosófico teria se tornado hegemônico no cenário político-cultural grego, negando e destronando outras orientações de pensamento que ali vigoravam, em especial a retórica, a sofística e os discursos artísticos) e um elogio aos discursos artísticos, mais especificamente à obra de arte da tragédia ática. Sócrates é apresentado como o grande inimigo da arte trágica, como aquele através de quem a tragédia grega teria sido levada ao ocaso e preterida em nome de um tipo de conhecimento que coloca a razão em primeiro plano. Tal conhecimento relega os sentidos, os instintos, as paixões e todos os elementos que as artes, de um modo geral, têm como substratos principais, a uma posição secundária, a um lugar de menor importância. Mais do que isso, 
em nome do triunfo da razão, estes elementos são caracterizados como empecilhos ao conhecimento, como entraves à obtenção de uma "verdade racional", que é considerada superior a qualquer conhecimento de cunho artístico.

O primeiro livro de Nietzsche apresenta, deste modo, uma crítica da tradição de pensamento racionalista que não prescinde, em momento algum, do elogio à arte. Como um antídoto ao culto à racionalidade que predomina na cultura ocidental, este texto faz uma apologia das verdades mais essenciais proporcionadas pela tragédia ática. Neste sentido, suas teses já demonstram, mesmo neste primeiro momento, um grande descontentamento em relação à tradição filosófica. Talvez pudéssemos dizer que a estratégia nietzschiana de contraposição à tradição de pensamento já possuía um caráter fortemente antirracionalista, embora não pudesse ainda ser caracterizada como antimetafísica, como acontece em seus últimos escritos. Isto porque Nietzsche ainda parte do repertório filosófico de Kant e Schopenhauer, filósofos que ele, mais tarde, passa a incluir na tradição de pensamento metafísico contra a qual se volta. Nietzsche ainda se apega à suposição de uma essência metafísica que resistiria por trás das aparências fenomenais, porque a própria vida é compreendida a partir de um fundamento transcendente. E, ainda que a arte já apareça como uma alternativa, ou como um antídoto contra os vícios da razão, isto acontece porque ela é vista como uma instância que colocaria o homem em contato com esta suposta essência superior do mundo, revelando suas verdades mais profundas.

Neste artigo, não abordarei os pormenores da interpretação nietzschiana acerca da tragédia ática, tampouco me deterei sobre os detalhes de sua contraposição ao racionalismo socrático como suposto meio de revelar as verdades mais essenciais da vida e de corrigir suas imperfeições. O objetivo deste texto é analisar em que medida, em O Nascimento da Tragédia (para além da contraposição ao racionalismo socrático e da aproximação com as filosofias de Kant e Schopenhauer como forma de elaborar seu peculiar elogio da tragédia ática), a caracterização pejorativa de Sócrates, como um antigrego e um como um moribundo, estaria diretamente relacionada a um pacto silencioso que Nietzsche estabelece com a perspectiva artística desenvolvida por Aristófanes em suas comédias.

Embora, em seu primeiro livro, Nietzsche suponha a existência de uma essência metafísica por trás do mundo fenomênico; embora ele lance mão de um elogio das "verdades essenciais" proporcionadas pelo conhecimento artístico contra as supostas verdades superiores da razão; e embora a própria vida seja compreendida também a partir de um fundamento supra-sensível (fatores que, de certo modo, limitariam a radicalidade de sua crítica, fazendo com ela se constituísse em uma crítica antirracionalista, mas não antimetafísica), a rejeição da tradição de pensamento racionalista já traz consigo algo do gesto que se radicaliza a partir de Humano, demasiado Humano, e que atinge o auge em seus últimos livros publicados. Isto pode ser depreendido, em grande parte, justamente do elogio feito à tragédia. A apologia aos discursos artísticos em contraposição ao 
conhecimento de origem metafísica que se delineia mais tarde em sua obra, já se insinua, ainda que de modo incipiente, em $O$ Nascimento da Tragédia, sobretudo pela ideia de que o conhecimento que se faz a partir de moldes artísticos superaria a racionalidade. Além disso, soma-se aqui outro tipo de aliança que Nietzsche estabelece com uma determinada forma de arte, mas que se dá de um modo quase silencioso, e que se configura muito mais nas entrelinhas desta primeira publicação. Trata-se da comédia antiga, um tipo de encenação que também tem origem em cultos dionisíacos e que também se encontra na raiz daquilo se configurou como o campo das práticas literárias. Entretanto, diferentemente da tragédia, por ser um dos principais veículos de crítica social na Grécia, a comédia só surge e se mantém viva enquanto tal durante o período histórico da democracia ateniense, quando a cultura democrática garantia a "liberdade de expressão" às contundentes críticas e sátiras que a comédia veiculava. A comédia antiga, mais precisamente aquela criada por Aristófanes (por ser um discurso ao mesmo tempo crítico e artístico que se coloca fora do campo delimitado pelo pensamento filosófico nascente), se constitui em uma aliada secreta de Nietzsche em sua contraposição à tradição de pensamento neste primeiro momento, e isto se dá tanto por um ponto de vista formal, quanto por um ponto de vista estratégico.

Se, em $O$ Nascimento da Tragédia, Nietzsche se volta contra a tradição de pensamento metafísico, elegendo Sócrates como o alvo privilegiado de seus ataques, esta não parece ser, de modo algum, uma escolha aleatória. Sócrates é historicamente tomado como a figura emblemática, através da qual, sobretudo no interior dos textos platônicos, o racionalismo pôde estabelecer as bases do discurso filosófico que inaugura a nossa tradição de pensamento. Por ele não ter jamais se dedicado à escrita, é somente através dos textos daqueles três autores que o retratam como um personagem de suas próprias obras - Platão, Xenofonte e Aristófanes - que, até hoje, se pode tomar contato com o que teria sido o conjunto dos ensinamentos socráticos. Contudo, dentre os textos destes três autores, os diálogos platônicos são os que gozam de um reconhecimento mais efetivo, são os que, até hoje, ainda ocupam um lugar diferenciado em relação aos escritos de Aristófanes e Xenofonte, talvez por aproximarem, mais do que os outros textos, o personagem Sócrates da figura ascética e sóbria do filósofo como o sábio. Xenofonte e Aristófanes, por outro lado, teriam sido negligenciados pela tradição. O primeiro, por ser considerado por historiadores como um espírito simplório, é tomado por alguém que não teria tido condições de apreender o que seria a dimensão ética dos ensinamentos socráticos, sendo acusado de empobrecer as ideias do mestre, de reduzi-las a simples lugares-comuns. Mas Aristófanes é quem se tornou o alvo maior de discriminação por parte da tradição de pensamento.

Por ser o grande representante da comédia antiga na Grécia (o único autor cômico cujas peças se conservaram, mesmo que não tenham sido todas), os textos de Aristófanes são considerados como obras em que a suposta seriedade de Sócrates teria sido anulada 
para ser revertida em instrumento de crítica social. Aristófanes, ao criar suas comédias, compõe, então, um personagem que, em função da perspectiva discriminatória da tradição, tornou-se desprezado por se tratar de um Sócrates risível, bufo e, portanto, falso aos olhos de tal tradição. Contudo, este personagem não deixa de revelar sutilezas importantes a serem consideradas por quem quer que tenha a intenção de formar uma imagem de Sócrates que não se atenha exclusivamente aos diálogos platônicos. O mais curioso é que, paralela e inversamente à recepção que a obra de Platão obteve, e à credibilidade que esta suscitou, a caracterização do personagem Sócrates, apresentada nos textos de Aristófanes, teria sido preterida pela tradição de pensamento. Motivo que talvez encontre justificativa justamente nas exigências que o Sócrates platônico confere aos discursos que pretendem alcançar o estatuto de legitimidade imposto pela racionalidade. Assim, o discurso socrático dos textos de Platão, que exige isenção e neutralidade como pré-requisitos para se atingir uma "verdade" adequada aos moldes da racionalidade, teria exercido certa sedução e influência em nossa cultura. Tal fato relegaria o Sócrates das comédias aristofanescas à quase clandestinidade. Assim, aos olhos da tradição de pensamento de origem socrático platônica, predominante no Ocidente, Aristófanes teria produzido um Sócrates ilegítimo, quando comparado ao Sócrates platônico.

Nietzsche, em $O$ Nascimento da Tragédia, no momento em que se dirige criticamente ao racionalismo socrático platônico, por meio desta contraposição mais específica a Sócrates, faz claramente uma escolha pelo personagem central dos textos de Platão como o principal alvo de seu ataque: uma escolha pelo ídolo privilegiado pela mesma tradição, desprezando o Sócrates que figura nas comédias de Aristófanes. Não é por acaso, portanto, que, na seção 14 do livro, a expressão usada para aludir a Sócrates de forma pejorativa é "o herói dialético no drama platônico". Nietzsche aborda, de uma forma mais direta, assuntos como a condenação socrática da tragédia como uma arte puramente instintiva, a aversão de Sócrates ao elemento dionisíaco manifesto através do coro e a necessidade de ultrapassagem da visão teórica do mundo como condição de possibilidade para um possível renascimento de uma postura trágica frente à vida. E o faz ao mesmo tempo em que anuncia em seu texto, quase de forma subliminar, outra questão que permanece sem ser extensamente desenvolvida neste livro, apenas indicada aqui, mas que reforça sua escolha pelo Sócrates platônico como alvo de ataques: trata-se da relação estreita entre Sócrates e Platão, entre mestre e discípulo, e das implicações de tal relação na obra deste último. Isto é, trata-se do problema de uma possível corrupção do jovem poeta Platão pelo mestre Sócrates e de como isto se reflete na própria estrutura formal dos textos platônicos. Trata-se, além disso, e por fim, do papel decisivo que tais diálogos tiveram no processo de consolidação da tradição de pensamento ocidental e da visão teórica do mundo, que se tornou a sua marca. 
Para atacar Sócrates, Nietzsche faz, então, uma escolha pelo personagem central dos diálogos de Platão cujo perfil ascético e sóbrio o identifica com a figura privilegiada do filósofo como o sábio por excelência. Mas o que também não está explícito neste primeiro livro, e que se mostra quase apenas em suas entrelinhas, é que, para tecer seus comentários pejorativos a respeito de Sócrates, Nietzsche estabelece uma aliança estratégica com Aristófanes. Aliança que se traduz, sobretudo, no modo pelo qual Nietzsche caracteriza Sócrates negativamente. Se a tradição de pensamento racional privilegia o Sócrates platônico e despreza o Sócrates aristofanesco, Nietzsche procura derrubar o mito erigido a partir dos textos de Platão, trazendo à tona uma imagem de Sócrates plenamente afinada com aquela veiculada pelas comédias de Aristófanes. O Sócrates aristofanesco, bufo, tomado como caricato e ilegítimo pela tradição (que escolhe o ídolo esculpido nos diálogos de Platão) é, sem dúvida, a imagem referencial a partir da qual Nietzsche constrói o perfil negativo que imprime ao Sócrates platônico. E isto fica mais claro e evidente quando se faz uma leitura de $O$ Nascimento da Tragédia à luz de comédias como, por exemplo, As Nuvens e As Rãs.

Em As Nuvens, Aristófanes narra de modo cômico a história de Strepsiades, um fazendeiro idoso e endividado, que, na esperança de poder enganar seus credores, tenta fazer seu filho aprender a sabedoria de Sócrates. Este último é um filósofo que, através de sofismas, ensina técnicas pelas quais seus discípulos aprendem a fazer o injusto passar por justo, a pior causa passar pela melhor. Para livrar-se de suas dívidas, Strepsiades vai, então, ao "pensatório", à "Oficina do Pensamento", e tenta se tornar discípulo de Sócrates (apresentado como filósofo-sofista). A partir daí, uma série de situações, de caráter, ao mesmo tempo, cômico e crítico em relação ao discurso da filosofia, à organização social e às instituições gregas do século V A.C., se desenrolam.

No aspecto formal, do ponto de vista da linguagem que Nietzsche e Aristófanes utilizam ao se referir criticamente a Sócrates, as aproximações possíveis entre $O$ Nascimento da Tragédia e As Nuvens são muitas. Aristófanes desmistifica a imagem ascética dos filósofos ao atribuir-lhes as características negativas que a própria filosofia cuidou de imputar aos sofistasi. Assim, ele apresenta Sócrates como um personagem estranhamente sábio, enigmático, sorrateiro, astuto e, também, enganador. Alguém que, mesmo sendo tomado pelas pessoas com as quais se relaciona como um homem sério, neutro e correto, não tem pudor ao fazer "trambiques", alguém que "escamoteia" para conseguir dinheiro ${ }^{\mathrm{ii}}$. Além disso, se, através do personagem Sócrates dos diálogos de Platão, a filosofia se esforça para expulsar tanto a sofística quanto à retórica e as artes em geral do chamado campo do pensamento legítimo, caracterizando-as pejorativamente como artes aduladoras (por estarem ligadas ao corpo, ao sensível, ao instintivo, ao agradável, e não à razão), Aristófanes, ao descrever Sócrates, mais uma vez o aproxima dos elementos que compõem a imagem negativa que a própria filosofia atribui a seus rivais. Ele cuida de 
trazer seu personagem socrático exatamente para o universo do sensível, do instintivo. Isto fica claro, por exemplo, logo no início de As Nuvens: Sócrates aparece em cena pela primeira vez "empoleirado" em uma cesta suspensa no ar, e os adjetivos que Aristófanes empresta tanto a ele quanto aos discípulos são, de um modo geral, depreciativos, e estão ligados não apenas ao corpo, que o Sócrates platônico repudia, mas ao corpo em estado de doença, à aparência mórbida, à falta de vitalidade - "pálidos", "cadavéricos", entre outros (Aristófanes, 1995, p.27) ${ }^{\text {iii }}$. Nietzsche, por sua vez, cria uma imagem para Sócrates que em muito se assemelha à imagem esculpida por Aristófanes, e também alude àquele por meio de adjetivos que, muitas vezes, lhe conferem um ar soturno e negativo. Tais adjetivos aparecem vinculados também ao âmbito do sensível, do corpo cujas forças encontram-se em desequilíbrio, do corpo cansado e, até mesmo, deformado. Provas evidentes disso são as expressões das quais ele lança mão seguidamente em seu texto: "monstruosidade per defectum" (em referência ao instinto socrático que se converte em crítico, e a consciência que se converte em criadora), "Sócrates moribundo" e "o grande e único olho ciclópico de Sócrates" (Nietzsche, 1996, § 13, § 15).

Fica evidente, assim, a aliança que Nietzsche estabelece com Aristófanes e como esta aliança se desdobra na própria caracterização crítica que Nietzsche faz de Sócrates em seu texto. Inspirado no Sócrates de Aristófanes, Nietzsche constrói o perfil negativo que atribui ao Sócrates platônico, e, a partir deste momento, tece seus comentários críticos em relação à própria tradição racionalista que se funda com os diálogos de Platão.

Além da linguagem semelhante, no que diz respeito às estratégias pelas quais se desenvolvem as críticas, os textos de Nietzsche e Aristófanes também se aproximam. Na seção treze de $O$ Nascimento da Tragédia, Nietzsche quase admite explicitamente que a estratégia, a partir da qual as suas próprias críticas a Sócrates, a Eurípides e à tradição de pensamento racionalista se estruturam, já se encontrava presente nas comédias de Aristófanes de modo muito semelhante. Isto, contudo, não acontece, e a aliança com a comédia aristofanesca fica refugiada nas entrelinhas do livro em questão. Nietzsche faz referência a Aristófanes, ao modo como este evidencia a proximidade entre Sócrates e Eurípides, à caracterização de Sócrates como um sofista em As Nuvens, e dá indicações de que, por ser produto da visão de um comediante, a denúncia tanto da existência de uma ligação entre Sócrates e Eurípides, quanto da existência de pontos de conexão entre a filosofia e a sofística feita por Aristófanes não teria sido levada a sério pela tradição de pensamento de origem socrático platônica. Nietzsche se refere aos nomes de Sócrates e Eurípides como aqueles que eram "pronunciados pelos "partidários dos bons velhos tempos",, dentre os quais inclui Aristófanes, "quando se tratava de enumerar os desencaminhadores do povo de então" (Nietzsche, 1996, § 13). De acordo com a argumentação de Nietzsche, Sócrates, como o defensor número um da racionalidade, teria encontrado em Eurípides um aliado. Ambos teriam tido uma influência negativa na 
civilização helênica, corrompendo os instintos mais nobres dos gregos, e fazendo com que a cultura mais elevada daquele povo fosse esvaziada pela necessidade de racionalização da vida. Este aspecto ressaltado nas páginas de $O$ Nascimento da Tragédia, segundo Nietzsche, também não teria escapado do olhar crítico de Aristófanes:

\begin{abstract}
De sua influência [de Sócrates e Eurípides] deriva, dizia-se, o fato de que a antiga, maratoniana e quadrada solidez do corpo e da alma seja vítima, cada vez mais, de um duvidoso Iluminismo, em uma progressiva atrofia das virtudes tradicionais. Nesse tom, meio indignado e meio desdenhoso, sói a comédia aristofanesca falar daqueles dois homens, para espanto dos modernos, que na verdade renunciam de bom grado a Eurípides, mas não podem parar de admirar-se que Sócrates apareça em Aristófanes como o primeiro e supremo sofista, como o espelho e o resumo de todas as aspirações sofísticas: diante disso, só lhes resta um consolo, o de colocar o próprio Aristófanes como um devasso e mentiroso Alcebíades da poesia. (Nietzsche , 1996, § 13)
\end{abstract}

Como mostra Nietzsche, Sócrates e Eurípides são igualmente apontados por Aristófanes como os representantes de um "iluminismo" corruptor dos gregos. Mas isto não quer dizer que esta imagem tenha sido aceita e associada aos dois nomes da mesma forma, ou que a tradição de pensamento socrático platônico sequer tenha admitido de bom grado que Sócrates (nome ligado às supostas qualidades da razão e à própria fundação do discurso filosófico) e Eurípides (nome ligado à arte) figurassem em um mesmo plano e que fossem responsabilizados pela decadência da cultura grega antiga nos mesmos termos. Em outras palavras, por ser Eurípides um artista, a "modernidade", acostumada a não colocar nunca seus holofotes sobre a arte, não teria criado resistências em relação à caracterização pejorativa que Aristófanes lhe empresta em suas comédias, ou, pelo menos, não teria feito grandes esforços no sentido de revertê-la. Por outro lado, segundo Nietzsche, a imagem de Sócrates como um sofista, criada por Aristófanes, não teria absolutamente sido acolhida por aqueles que Nietzsche, a seu modo, denomina modernos. Estes, por encontrarem as origens do tipo de pensamento que cultivavam e idolatravam nos diálogos platônicos em que Sócrates aparece ligado à figura acética do sábio, do homem moralmente correto, jamais poderiam compactuar com a visão crítica aristofanesca. Quando colocada em xeque pela interpretação que Aristófanes apresenta de Sócrates, e quando forçada a se definir pelas comédias ou pelos diálogos platônicos, a tradição socrático platônica teria privilegiado a imagem do personagem esculpido por Platão, e, a exemplo do que a filosofia faz com as artes em geral, teria afastado Aristófanes e seu Sócrates supostamente caricato para o campo do falso, do ilegítimo, do risível. Por isso Nietzsche afirma que os modernos teriam resolvido seu problema colocando Aristófanes na condição de "devasso e mentiroso Alcebíades da poesia".

Nietzsche não compactua com a postura que a tradição racionalista mantém em relação a Aristófanes. Ao contrário, volta-se contra ela, e, mesmo que quase 
silenciosamente, traz as estratégias aristofanescas de crítica a Sócrates, a Eurípides e ao próprio discurso filosófico para dentro das argumentações de seu primeiro livro ${ }^{\text {iv }}$. Ao fazer de Sócrates um filósofo sofista (ou um sofista filósofo), Aristófanes denuncia a filosofia como um tipo de discurso que se volta contra a própria sofística que também lhe teria dado origem: ele desmascara a filosofia como uma prática discursiva que, através de técnicas argumentativas veiculadas também pela sofística, condena o discurso sofístico por este se utilizar de métodos supostamente escusos, por ele ser "ilegítimo", "falso", desvinculado da "verdade" aspirada e pretensamente atingida pela filosofia.

Nietzsche, ao se voltar contra o racionalismo socrático platônico, não deixa de transpor para dentro de seu texto a mesma lógica que vigora no raciocínio crítico de Aristófanes. Na seção quatorze de seu livro, Nietzsche se refere aos diálogos platônicos como um tipo de discurso artístico que estranhamente nega a arte em seu interior. Segundo a argumentação nietzschiana, por ter sido um poeta antes de se render aos ensinamentos do mestre Sócrates, Platão não teria conseguido renunciar suas origens artísticas, e teria feito de seus diálogos "o bote em que a velha poesia naufragante se salvou com todos os seus filhos" (Nietzsche, 1996, § 14). Em outras palavras, Platão teria trazido para seus diálogos, que supostamente se opõem de modo radical a toda arte, a poesia à qual ele se dedicara antes de se tornar discípulo de Sócrates. Tais diálogos, segundo o raciocínio de Nietzsche, seriam textos híbridos, que oscilam entre razão e arte, e acabam submetendo esta última à primeira. Pela interpretação nietzschiana, Platão, ao condenar a arte em seus diálogos, o faria também por meios artísticos, e estaria criando uma poesia submissa às regras da razão, uma poesia que se volta contra a própria poesia, uma arte que se volta contra a própria arte. Quando apresenta o diálogo platônico como um texto híbrido, Nietzsche faz vigorar em seu livro o mesmo regime de pensamento que guiava Aristófanes em suas críticas cômicas. Se, pela perspectiva aristofanesca, a filosofia, ao ser representada em As Nuvens pelo Sócrates sofista, poderia ser interpretada criticamente como uma espécie de sofística que se volta contra a própria sofística; pela perspectiva nietzschiana, os diálogos platônicos, na medida em que possibilitam a fundação da tradição de pensamento racionalista, tendo como símbolo o personagem Sócrates filósofo, podem ser interpretados criticamente como um discurso artístico que se volta contra a arte, como poesia voltada contra a própria poesia.

Ficam evidentes, assim, as estratégias correlatas dos textos de Nietzsche e Aristófanes. Ambos, em suas críticas, mostram-se sensíveis e perceptivos ao que parece ser a lógica a partir da qual o pensamento de origem socrático platônica pôde se constituir: para se estabelecer como um tipo de pensamento legítimo, a filosofia que se funda nos moldes do racionalismo socrático precisa, em primeiro lugar, negar os discursos que ela toma como lhe sendo opostos, mas que não passam de práticas discursivas das quais a própria filosofia teria nascido. Dito de outro modo, a filosofia, para se fortalecer, cria uma oposição imaginária entre o que seria o seu território próprio e o território inimigo. Mas este 
território que é compreendido, de antemão, como inimigo, não deixa de ser o próprio campo do qual a filosofia se origina. Vista deste modo, a filosofia, a partir de Nietzsche, sob a inspiração aristofanesca, poderia ser interpretada não como um tipo de pensamento que em sua própria origem se oporia à arte, e muito menos como um discurso superior aos discursos artísticos. Pelo olhar nietzschiano, a filosofia seria, antes, um subconjunto da arte. Subconjunto que nega suas origens, e que se volta contra a arte. Aristófanes, talvez por ser um comediante, e por ter vivenciado o contexto político cultural da Grécia democrática que torna possível e garante o caráter crítico contundente das comédias antigas, demonstra ter percebido esta lógica pela qual a filosofia se relaciona com seus supostos rivais, e a evidencia em suas comédias tematizando especificamente a relação mais direta e a disputa de caráter político entre os discursos filosófico e sofístico. Nietzsche, por outro lado, talvez por aderir parcialmente à metafísica da arte de Schopenhauer, mostra-se também perceptivo à estratégia pela qual o discurso filosófico se forma, mas evidencia a lógica interna de funcionamento e constituição de tal discurso a seu próprio modo. Sem deixar de reconhecer o caráter político da disputa que a filosofia mantém com a sofística, Nietzsche privilegia a relação que a filosofia guarda em suas origens socrático platônicas com a poesia. Ao se referir ao diálogo platônico como o bote em que a poesia naufragante se salva com todos os seus filhos, Nietzsche abre espaço para que, entre estes filhos, sejam incluídas todas aquelas práticas discursivas às quais a filosofia se opõe e com as quais, apesar disso, ela estaria intimamente aparentada: a sofística, a retórica, a própria pintura, entre outras. Insinuam-se, assim, já em seu primeiro livro, alguns elementos que aparecem de um modo bem mais ostensivo em seus escritos posteriores, quando a crítica a Platão torna-se muito mais direta, e a problemática relação que este teria estabelecido com Sócrates passa a ser intensamente explorada.

A denúncia de que a filosofia seria no mínimo intimamente aparentada com os discursos contra os quais ela se volta não é a única afinidade da crítica nietzschiana com a crítica aristofanesca. A relação entre Sócrates e Eurípides, e a caracterização deste último como um poeta responsável pela criação de um drama decadente, que nega os valores mais elevados da cultura helênica, também é um tema primeiramente referido por Aristófanes, de uma forma muito próxima àquela que vem a ser trabalhada por Nietzsche. Em As Rãs, Aristófanes narra um episódio em que Dioniso, depois das mortes de Eurípides, Sófocles e Ésquilo, frustrado com a ausência de bons poetas trágicos, resolve ir ao Inferno para resgatar de lá um dos dois artistas que se dispusesse a voltar à vida. Mas, para que apenas um dos autores que se encontravam no Hades volte com Dioniso, cria-se, então, um concurso através do qual se decidirá, entre os candidatos que se apresentem, qual deles deve figurar como o melhor poeta trágico. Inicia-se, assim, uma disputa entre Ésquilo e Eurípides, e Dioniso, na condição de juiz, escolhe Ésquilo como vencedor. 
Nesta comédia, os pontos de concordância entre Nietzsche e Aristófanes ficam ainda mais claros. Praticamente todos os traços que Nietzsche reprova em Eurípides, em $O$ Nascimento da Tragédia, também compõem o perfil deste último nas páginas de As Rãs. Perfil que, ao final da peça, com a derrota de Eurípides para Ésquilo, acaba por se configurar também como negativo, mostrando uma sintonia entre os posicionamentos críticos de Nietzsche e Aristófanes. $\mathrm{Na}$ discussão que trava diretamente com Ésquilo, Eurípides tenta provar sua suposta superioridade em relação ao concorrente. Os argumentos utilizados por Eurípides contra seu predecessor, em $A s$ Rãs, são praticamente os mesmos que, segundo Nietzsche, em seu livro, Sócrates usa contra a tragédia (o que também mostra um paralelismo entre os textos de Nietzsche e Aristófanes). Além disso, o modo como Eurípides ataca Ésquilo para defender a racionalidade de seus próprios dramas trágicos, na comédia de Aristófanes, ilustra perfeitamente as teses desenvolvidas por Nietzsche, segundo as quais, as exigências do racionalismo socrático teriam sido não só respeitadas por Eurípides, mas levadas adiante por este e incorporadas nos dramas euripidianos. As Rãs configura-se, assim, como o próprio texto do qual Nietzsche parece partir para desenvolver seus principais argumentos contra Eurípides em $O$ Nascimento da Tragédia - mostrando como este estaria diretamente ligado à tendência racional socrática. Esta fonte, contudo, não é explicitada por Nietzsche em seu livrov .

No texto de Aristófanes, Eurípides tenta ridicularizar o rival acusando-o de ser "vaidoso", "charlatão", de iludir os espectadores simplórios, de nada escrever de inteligível, e, em seguida, se gaba por cumprir todos esses pré-requisitos que, para ele, garantiriam a qualidade de um drama trágico (Aristófanes, 1996, pp. 252 - 253). Nietzsche, por sua vez, em $O$ Nascimento da Tragédia, argumenta que Eurípides "levou o espectador ao palco, a fim de torná-lo verdadeiramente apto ao ajuizamento" (Nietzsche, 1996, § 11), como se o papel mais importante da tragédia fosse o de ensinar o espectador a compreender, o de leválo a ser capaz de fazer julgamentos a partir de tramas apresentadas de modo linear e acessível às mentes mais simplórias. Reforça-se, assim, o paralelo entre os textos de Nietzsche e Aristófanes. O que ocorre é que praticamente todos os elementos apontados por Nietzsche como características negativas próprias ao socratismo estético (tendência da qual Eurípedes seria o representante) também já teriam sido diagnosticados por Aristófanes como elementos negativos através do próprio modo pelo qual ele esculpe criticamente a imagem de Eurípedes. Duas das falas deste último, em $A s$ Rãs, são especialmente representativas a este respeito:

Não apresentei no palco nem galos enormes nem 'capriveados', seguindo seu exemplo, e tais como eles são vistos em tapetes persas. Recebi de suas mãos uma tragédia totalmente sobrecarregada de exageros bombásticos e de uma pesada bagagem de palavras enormes; primeiro tornei mais leve o peso dela, e diminuí essa inchação por meio de versinhos, de 
digressões (...); depois a nutri com monólogos (...); o primeiro ator a entrar em cena expunha desde logo os antecedentes da peça. (Aristófanes, 1996, p. 258)

E ainda:

Pus em cena os hábitos da vida cotidiana, coisas banais, familiares, sobre as quais cada espectador estava em condições de julgar. Não me esforçava por confundir a inteligência com um estrépito de palavras, nem por encher de espanto o espectador. (Aristófanes, 1996, p. 260)

Aristófanes, em sua comédia, empresta a Eurípides praticamente todos os elementos contra os quais Nietzsche se volta ao tratar do socratismo estético: a transposição da vida do homem comum para o palco; a elevação do espectador simplório à condição de juiz do drama; a necessidade de a razão guiar dialeticamente a construção das falas das personagens; a exigência de inteligibilidade dos diálogos; a necessidade da criação do prólogo como forma de expurgar da tragédia os elos perdidos e as tensões sem resolução, e de, enfim, garantir o entendimento mesmo do espectador mais incapacitado. Embora não sejam explicitados por Nietzsche em seu livro, ficam evidentes os pontos de convergência entre a perspectiva crítica de Aristófanes em relação a Eurípides e a visão crítica de Nietzsche, o que coloca Eurípides como representante da tendência socrática nas artes.

O desfecho da disputa entre os dois poetas encenada por Aristófanes traz ainda um dado tão cômico quanto sinalizador da sintonia entre os textos de As Rãs e $O$ Nascimento da Tragédia. Tentando apontar supostos erros nos dramas de Ésquilo, Eurípides propõe uma discussão a respeito da função cumprida pelos prólogos em cada um dos autores. Ele pede ao concorrente que recite o primeiro prólogo da trilogia Oréstia (trilogia que compreende tragédias de temas correlatos: Agamênon, Coéforas e Eumênides) e, após ter seu pedido atendido, aponta vários "defeitos" nos versos apresentados por Ésquilo. Em seguida, dedica-se a exaltar o seu trabalho de correção no sentido de tornar o início da tragédia inteligível, acessível ao homem comum, tarefa que ele próprio teria cumprido ao reescrever não apenas o prólogo de Agamênon, mas toda a trilogia, transformando-a em Electra. Ésquilo reage aos argumentos de Eurípides através de um verdadeiro desmonte das exigências racionais de seu rival, e, com o humor que Aristófanes imprime ao texto ${ }^{\mathrm{vi}}$, vence a disputa, consagrando-se o melhor poeta trágico. Ao fim da peça, um detalhe arremata a comédia e, ao mesmo tempo, deixa claro que Aristófanes evidencia Sócrates como o grande inimigo da arte trágica. O coro das rãs saúda o vencedor, comemora a escolha de Dioníso, reafirma o papel da música como elemento mais importante do drama trágico, e aconselha Ésquilo a se distanciar o máximo possível do grande antípoda da cultura trágica, daquele que, também segundo Nietzsche, teria sido o responsável pela morte da tragédia por trás da obra de Eurípides: 
Feliz o homem totalmente sábio! Milhares de provas atestam a veracidade desta afirmação. Este, por ter sido sábio, voltará a ver a sua casa, o que é uma vantagem para seus concidadãos, para seus parentes e seus amigos; ele deverá tudo à sua sapiência. É bom, então, não ficar perto de Sócrates conversando com ele, desdenhando a música e as partes mais importantes da arte trágica. É loucura perder tempo em conversas ociosas, em sutilezas frívolas. (Aristófanes, 1996, p. 288)

Pela fala do coro cômico, Aristófanes reafirma a força do coro trágico, coloca a música de volta ao ponto de origem da tragédia, e, ao mesmo tempo, aponta para as figuras de Sócrates e Eurípides como os representantes de uma arte que se desvia do caminho das grandes tragédias - simbolizadas, neste texto, por Ésquilo. Nietzsche, em sua primeira publicação, sem mencionar explicitamente a comédia aristofanesca, ratifica a perspectiva desenvolvida em $A s$ Rãs, e evidencia ainda mais a ligação entre Sócrates e Eurípides, colocando este último como o poeta do socratismo estético.

Os textos de As Rãs e O Nascimento da Tragédia colocam-se, assim, em um mesmo patamar no que se refere à contraposição à tendência teórica representada pelos nomes de Sócrates e Eurípides. Tendência que teria prevalecido sobre os elementos mais caros à cultura trágica, e que teria, por isso, sido responsável pelo movimento decadente que tal cultura vê se iniciar a partir de então. As aproximações possíveis entre Nietzsche e Aristófanes, a partir da comparação entre seus respectivos escritos, são significativas: ambos mostram Eurípides como aquele que teria cumprido as exigências socráticas de racionalização do drama, e, por isso, seria um poeta trágico decadente. Ambos desenvolvem a mesma postura crítica em relação a Sócrates, apontando-o como a figura que age por trás de Eurípides. Sócrates seria, assim, responsável pelas transformações no modo de encarar as artes em geral, e estas transformações, transpostas para dentro do drama pela ação direta de Eurípides, teriam resultado na morte da tragédia. Ambos, também, valorizam a arte trágica tradicional, a música dionisíaca e o caráter irracional que esta faz se manifestar nos grandes dramas de Ésquilo e Sófocles. Neste sentido, a partir dos preceitos racionais socráticos e da produção de Eurípides, segundo Nietzsche, e de acordo com a visão que já aparece primeiramente em Aristófanes, com a preponderância desta tendência (que termina por dominar toda a cultura grega), produz-se uma nova e decadente arte. Uma arte que, por colocar a razão como juíza e algoz dos instintos, das paixões, e do que há de mais essencial na tragédia - a música, faz o efeito trágico se dissipar diante das exigências de inteligibilidade, de linearidade e de moralização do drama.

A crítica de Nietzsche à tradição de pensamento, em suas origens, socrático platônicas, feita em $O$ Nascimento da Tragédia, poderia ser interpretada, a partir do que expus até aqui, como um gesto tipicamente cômico. Gesto que teria vindo à tona pela primeira vez através de Aristófanes. A crítica ao personagem Sócrates dos diálogos de Platão, ao chamado otimismo teórico e ao socratismo estético, bem como o elogio da arte trágica feitos por Nietzsche neste livro pressupõem, antes de tudo, uma aliança com a 
comédia aristofanesca, e isto se dá não apenas por um ponto de vista formal, mas também por um ponto de vista eminentemente estratégico.

Se Nietzsche, ao escrever seu primeiro livro, parte de conceitos que remetem ao repertório filosófico de Kant e Schopenhauer, e também de algumas das teses destes dois, isto acontece principalmente porque tais filosofias encarnariam um caráter crítico em relação à tradição de pensamento racional de origem socrático platônica. $O$ uso da linguagem kantiana e schopenhaueriana permite a Nietzsche desenvolver sua crítica no interior daquele que historicamente tornou-se identificado como o universo propriamente filosófico. E isto (mesmo levando-se em conta a própria recepção nada calorosa que seu livro de estreia) fez, ou pelo menos teria feito, com que Nietzsche fosse, de certo modo, ouvido dentro deste universo, algo que Aristófanes, por desenvolver um discurso artístico cômico, não teria conseguido. Contudo, quando se comparam os textos de Nietzsche e Aristófanes, o que fica evidente é que mesmo esta parcial aliança de Nietzsche com Kant e Schopenhauer estaria, de antemão, submetida ao pacto mais forte que ele faz com a arte cômica.

O Nascimento da Tragédia teria concretizado, assim, ao mesmo tempo, a apropriação das filosofias críticas de Kant e Schopenhauer, o abandono, em determinado ponto, destas mesmas teses em função dos caminhos próprios que Nietzsche prefere seguir (exemplo maior disso seria o próprio desenvolvimento da ideia do consolo metafísico, que, embora tenha sido gerada com base na metafísica da arte schopenhaueriana, acaba indo em uma direção diametralmente oposta à das teses de Schopenhauer sobre a tragédia) e, por fim, mas não em último lugar, a adesão intensa de Nietzsche à perspectiva artística de Aristófanes. O Nascimento da Tragédia seria a realização, em filosofia, de uma crítica ao socratismo e de um elogio à tragédia que, originalmente, se fazem a partir da perspectiva da arte cômica. As teses que ali se delineiam teriam uma origem exterior à tradição de pensamento metafísico: seriam teses antissocráticas e, sobretudo, cômicas. 


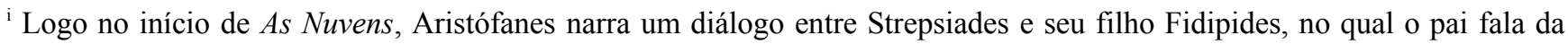
casa de Sócrates, o "pensatório", como um reduto de sábios. As qualidades atribuídas aos frequentadores do pensatório - os filósofos, sábios - são, entretanto, as mesmas com as quais a filosofia constrói a imagem negativa da sofística: "Strepsiades - Ali é o 'pensatório', a escola dos espíritos sabidos. Lá dentro vivem pessoas que, falando a respeito do céu, nos convencem de que ele é um forno que cobre a gente e de que a gente é o carvão dele. Aqueles caras ensinam os outros, se eles quiserem contribuir com algum dinheiro, a tornarem vitoriosas todas as causas, justas ou injustas, usando só as palavras". (Aristófanes. 1995, p.18).

${ }^{\text {ii }}$ Uma passagem específica ilustra bem este aspecto do texto. Trata-se de um momento em que o coro das Nuvens se dirige a Sócrates, no intervalo em que Strepsiades sai de cena e vai buscar seu filho, que se tornará um discípulo frequentador do "pensatório": "Coro - Você imagina os muitos benefícios que colherá agora mesmo graças a nós, somente nós entre todos os deuses? De fato, nosso homem está pronto a fazer tudo que você mandar. Enquanto o coroa está fora de si e visivelmente entusiasmado, sabendo disso você vai arrancar dele o máximo possível, e depressa, pois as coisas estão tomando por si mesmas um rumo inesperado". (Aristófanes, 1995, p. 61).

iii Mesmo quando Aristófanes se refere a Sócrates em tom elogioso, ele sempre o faz com ironia. Com isso, aquilo que deveria, a princípio, designar uma qualidade positiva se converte também em chacota, em instrumento crítico. A própria entrada de Sócrates em cena em As Nuvens exemplifica bem este recurso. Strepsiades vê Sócrates e, sem reconhecê-lo, sem saber de quem se trata, pergunta: "Olhe ali! Quem é aquele cara que está empoleirado naquela cesta suspensa no ar?". A orientação cênica de Aristófanes exige que a resposta do discípulo se dê, segundo suas próprias palavras, "Com ar de beatitude: - Sócrates!”. (Aristófanes, 1995, p. 27). Esta fala, levada ao palco em uma comédia, e dita com ar solene, reverte um suposto ato respeitoso em deboche escrachado, mostra o gesto crítico de Aristófanes em relação à imagem ascética que a filosofia confere ao filósofo como um ser superior.

${ }^{\text {iv }}$ Depois da referência nominal a Aristófanes no trecho citado acima, Nietzsche continua: "Sem tomar neste ponto a defesa dos profundos instintos de Aristófanes contra semelhantes ataques, sigo adiante para demonstrar, a partir do sentimentos dos Antigos, a estreita afinidade existente entre Sócrates e Eurípides". (Nietzsche, 1996, § 13). Ao dizer que segue a partir do sentimento dos antigos, Nietzsche não faz outra coisa senão incorporar a lógica da crítica aristofanesca a seu próprio texto. Fortalece-se, com isso, de forma discreta, quase silenciosa - como venho frisando - o elo entre Nietzsche e Aristófanes.

${ }^{v}$ Embora, em $O$ Nascimento da Tragédia, Nietzsche não deixe explícita a ligação entre as argumentações críticas que ele ali desenvolve e a caracterização pejorativa de Sócrates e Eurípides produzida nos textos de Aristófanes, na conferência Sócrates e a Tragédia - que, junto com O Drama Musical Grego e A Visão Dionisíaca do Mundo, compõe os escritos preparatórios de seu primeiro livro publicado, e que data de fevereiro de 1870 -, ele faz referência nominal a Aristófanes, e chega mesmo a citar alguns trechos de As Rãs. Tais citações acabam por funcionar como ponto de partida, ou como texto base a partir do qual Nietzsche constrói o perfil negativo emprestado a Eurípides e a Sócrates, tanto nesta conferência, quanto em sua primeira publicação. Mas o que ocorre é que, curiosamente, ainda que grande parte das argumentações desenvolvidas em "Sócrates e a Tragédia" tenham sido incorporadas em O Nascimento da Tragédia, neste último, as citações do texto de $A s$ Rãs foram suprimidas, e a sintonia entre as perspectivas nietzschiana e aristofanesca se esconde nas entrelinhas do livro. Isto, como mostrarei um pouco mais à frente, talvez se dê em função da adesão parcial de Nietzsche às filosofias de Kant e Schopenhauer, e daquilo que esta adesão representava em termos de receptividade do livro junto a um público propriamente "filosófico". A aliança de Nietzsche com estes filósofos, embora não seja mais intensa do que aquela que ele estabelece com Aristófanes, permite que ele desenvolva suas críticas à tradição de pensamento com uma roupagem que facilitaria a aceitação de suas teses no interior do universo da filosofia. Talvez por isso a aproximação de Nietzsche em relação a Kant e Schopenhauer tenha ganhado o primeiro plano em sua publicação - enquanto que a proximidade com Aristófanes permanece oculta.

${ }^{\mathrm{vi}}$ Aristófanes ridiculariza Eurípides pela boca do personagem Ésquilo, ao fazer com que, no início de cada prólogo recitado por Eurípides, Ésquilo o interrompa, introduzindo inesperadamente, mas de forma a se manter certa coerência, a frase "... e perdeu sua garrafinha" (Aristófanes, 1996, pp. 273 - 276). Em todos os trechos referidos por Eurípides, este rótulo se encaixa, ao mesmo tempo, interrompendo a linearidade das frases originais, dando-lhes outro sentido, e tornando-as ridículas, cômicas.

\section{Referências Bibliográficas:}

ARISTÓFANES. As Nuvens. Tradução de Mário da Gama Kury. Rio de Janeiro: Jorge Zahar Editor, 1995. 
. As Rãs. Tradução de Mário da Gama Kury. Rio de Janeiro: Jorge Zahar Editor, 1996.

KANT, Immanuel. Obras incompletas. Tradução de Valerio Rohden e Udo Baldur Moonsburguer. São Paulo: Abril Cultural, 1974.

NIETZSCHE, Friedrich. A visão Dionisíaca do Mundo. Tradução de Marcos Sinésio Pereira Fernades e Maria Cristina dos Santos de Souza. São Paulo: Martins Fontes, 2005.

.Ecce Homo. Tradução de Paulo César Souza. São Paulo: Companhia das Letras, 1995. 1996.

. O Nascimento da Tragédia. Tradução de J. Guinsburg. São Paulo: Companhia das Letras,

. Humano, demasiado Humano. Tradução de Paulo César Souza. São Paulo: Brasiliense, 2000.

SCHOPENHAUER, Arthur. Obras Incompletas. Tradução de Wolfgan Leo Maar e Maria Lúcia Mello e Oliveira Cacciola. São Paulo: Abril Cultural, 1980. 